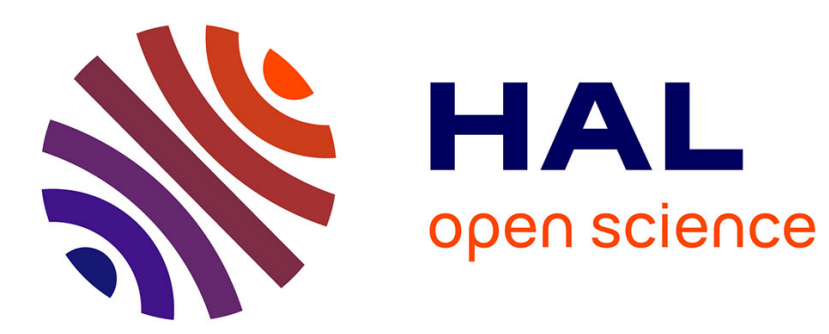

\title{
Higher soybean yield by inoculation with N-fixing and P-solubilizing bacteria
}

Aftab Afzal, Asghari Bano, Mussarat Fatima

\section{To cite this version:}

Aftab Afzal, Asghari Bano, Mussarat Fatima. Higher soybean yield by inoculation with N-fixing and P-solubilizing bacteria. Agronomy for Sustainable Development, 2010, 30 (2), 10.1051/agro/2009041 . hal-00886496

\section{HAL Id: hal-00886496 https://hal.science/hal-00886496}

Submitted on 1 Jan 2010

HAL is a multi-disciplinary open access archive for the deposit and dissemination of scientific research documents, whether they are published or not. The documents may come from teaching and research institutions in France or abroad, or from public or private research centers.
L'archive ouverte pluridisciplinaire HAL, est destinée au dépôt et à la diffusion de documents scientifiques de niveau recherche, publiés ou non, émanant des établissements d'enseignement et de recherche français ou étrangers, des laboratoires publics ou privés. 


\title{
Higher soybean yield by inoculation with $\mathbf{N}$-fixing and P-solubilizing bacteria
}

\author{
Aftab AfZAL, Asghari BANO*, Mussarat FATIMA \\ Department of Plant Sciences, Faculty of Biological Sciences, Quaid-i-Azam University Islamabad, Pakistan
}

(Accepted 25 September 2009 )

\begin{abstract}
Phosphorus availability for soybean growth is frequently low because P reacts with iron, aluminum and calcium in soil to form insoluble phosphates. The increasing price of phosphatic fertilizers is a major obstacle faced by farmers for application of recommended $\mathrm{P}$ doses. Low yield of soybean in Pakistan is also lowering adoption by farmers of this oilseed crop. These issues could be solved by inoculation of beneficial microorganisms that enhance the availability of $\mathrm{N}$ and $\mathrm{P}$ to the plant. Here, we tested the effect of inoculation of Bradyrhizobium or Pseudomonas, or both, in the presence and absence of $\mathrm{P}_{2} \mathrm{O}_{5}$ fertilizer, on soybean yield. Experiments were carried out in pots and the field during 2004 and 2005 under natural conditions. The bacterial strains were applied in broth culture in the pots at the seedling stage or as a seed treatment in the field. Our results showed that co-inoculation of Bradyrhizobium and Pseudomonas strains with the $\mathrm{P}_{2} \mathrm{O}_{5}$ treatment resulted in increased grain yield of $38 \%$ in pot experiments and $12 \%$ in the field experiment, compared with the $\mathrm{P}_{2} \mathrm{O}_{5}$ treatment alone. Bradyrhizobium japonicum strain TAL 377 produced $74.64 \mu \mathrm{g} / \mathrm{mL}$ indole acetic acid and $261.2 \mu \mathrm{g} / \mathrm{mL}$ gibberellic acid. Similarly, Pseudomonas strain $54 \mathrm{RB}$ produced $8.034 \mu \mathrm{g} / \mathrm{mL}$ indole acetic acid and $1766 \mu \mathrm{g} / \mathrm{mL}$ gibberellic acid. The survival efficiency of Bradyrhizobium was up to $46 \%$ higher due to co-inoculation and $\mathrm{P}_{2} \mathrm{O}_{5}$ as compared with its single inoculation. On the other hand, Pseudomonas survival efficiency was up to 33\% higher with added $\mathrm{P}_{2} \mathrm{O}_{5}$ as compared with its single inoculation.
\end{abstract}

Bradyrhizobium / Pseudomonas / co-inoculation / soybean / survival efficiency

\section{INTRODUCTION}

Soybean is one of the most important oilseed crops in the world. Soybean has the highest protein content (40-42\%) of all other food crops and is second only to groundnut in terms of oil content (18 to 22\%) among food legumes (Robert, 1986). In Pakistan, it is grown on a very small area at present, only in Sindh and the North-Western Frontier Province. Average yield of soybean in the country is low as compared with other soybean-growing countries. The problem is the low soil fertility, especially nitrogen and phosphorus deficiency in Pakistani soils due to intensive cropping, low inputs and $\mathrm{P}$ fixation in calcareous soils coupled with high fertilizer prices, especially phosphatic fertilizers. So, this is a comparative study of the effects of $\mathrm{P}_{2} \mathrm{O}_{5}$ application and inoculation with Pseudomonas and Bradyrhizobium on available P content of soil, and ultimately the soybean yield.

The $\mathrm{P}$ bioavailability is a major factor limiting nitrogen fixation (Israel, 1987) and P deficiency could inhibit the nodule development and thereby the total $\mathrm{N}_{2}$ fixation (Miao et al., 2007). Although $\mathrm{N}$ and $\mathrm{P}$ fertilizers will continue to play a major role in intensive agriculture, depletion of natural resources,

* Corresponding author: asgharibano@yahoo.com high input costs, and long-term unsustainability necessitate alternative strategies be investigated and implemented to buffer against food insecurity and environmental degradation. Furthermore, because improved $\mathrm{N}$ and $\mathrm{P}$ use by plants has an immediate and direct benefit in extensive agriculture in developing countries where access to fertilizers is limited, efforts in research focused on improved nutrient efficiency should be a high priority (Vance, 2001).

Microorganisms involved in biofertilizer production can play a major role in increasing nutrient availability for high yield and reducing production cost by limited chemical fertilizer application. Phosphorus biofertilizers could help increase the availability of phosphate for plant growth by solubilization, promoting the plant growth through production of plant growth-promoting substances, and by increasing the efficiency of biological nitrogen fixation (Kucey et al., 1989). Although the role of phosphorus fertilizers in nodulation, nitrogen fixation, nutrient-use efficiency and growth of soybean has been reported (Israel, 1987; Tsvetkova and Georgiev, 2003; Israel, 2006; Miao et al., 2007), information is scanty regarding the role of phosphate-solubilizing bacteria in phosphorus bioavailability, growth promotion and also their interaction with $\mathrm{N}_{2}-$ fixing bacteria. 
Co-inoculation of Bacillus strains onto soybean plants with Bradyrhizobium japonicum provided the largest and most consistent increases in nodule number, nodule weight, shoot weight, root weight, total biomass, total nitrogen and grain yield (Bai-Yu Ming et al., 2003). The present investigation aimed to evaluate the efficiency of Pseudomonas and Bradyrhizobium in order to use them as a combination in biofertilizer for nutrient availability and subsequent yield improvement of soybean. An experiment under axenic conditions was also conducted to determine the survival efficiency of Bradyrhizobium and Pseudomonas alone and in coinoculation in the rhizosphere during early vegetative growth of soybean, and also to estimate the magnitude of interaction of the two microorganisms applied simultaneously.

\section{MATERIALS AND METHODS}

The Pseudomonas sp. strain 54RB and Bradyrhizobium strain TAL 377 were obtained from the Soil Biology and Biochemistry Lab. of the National Agricultural Research Center (NARC), Islamabad. This Pseudomonas strain has not been evaluated before for its potential alone as a phosphorus solubilizer or in association with $\mathrm{N}$-fixing bacteria for soybean. Soybean seeds (cv. NARC 7) were obtained from the Oil Seed Program, NARC, Islamabad.

\subsection{Pot experiment}

Clay pots $(24 \times 36 \mathrm{~cm})$ were filled with $10 \mathrm{~kg}$ soil collected from uncultivated land situated in Shahdra near Quaid-I-Azam University, Islamabad, and well mixed with sand at 1:1 in order to make it porous for easy and accurate root nodule sampling. The final mixture had sandy loam soil texture, $\mathrm{pH}$ 7.9, EC $0.43 \mathrm{dsm}^{-1}$, P content $10 \mathrm{ppm}$ and $\mathrm{NO}_{3}-\mathrm{N} 15 \mathrm{ppm}$. Ten seeds were sown in each pot (six pots per treatment). After germination, five plants per pot were maintained for growth until maturity. The experiment was conducted under natural conditions in 2004 and 2005 with temperature varying from $20{ }^{\circ} \mathrm{C}-32{ }^{\circ} \mathrm{C}$, total rainfall $481 \mathrm{~mm}$, relative humidity ranging from $77-86 \%$ and the photoperiod ranging from $10-13 \mathrm{~h}$.

A starter dose of nitrogen of $0.3 \mathrm{~g} /$ pot (equivalent to $30 \mathrm{~kg} / \mathrm{ha}$-recommended dose) was applied in the form of urea in each pot, whereas $\mathrm{P}_{2} \mathrm{O}_{5}$ was applied at $1.35 \mathrm{~g}$ per treatment pot (equivalent to $50 \mathrm{~kg} /$ ha-recommended dose) in the form of Single Superphosphate (SSP) only in treated pots. Plants were watered as required to maintain moisture at field capacity and harvested at maturity for grain and straw yield after a growth period of 11 weeks.

The treatments included a non-inoculated control, $\mathrm{P}_{2} \mathrm{O}_{5}$, Pseudomonas, Bradyrhizobium, Bradyrhizobium and $\mathrm{P}_{2} \mathrm{O}_{5}$, Pseudomonas and $\mathrm{P}_{2} \mathrm{O}_{5}$, Bradyrhizobium and Pseudomonas, and Bradyrhizobium, Pseudomonas and $\mathrm{P}_{2} \mathrm{O}_{5}$. Each treatment was replicated six times. The Pseudomonas inoculum was prepared in Pikovskaya medium (Pikovskaya, 1948) [containing insoluble tricalcium phosphate $2.5 \mathrm{~g}$, glucose $13 \mathrm{~g},\left(\mathrm{NH}_{4}\right) \mathrm{SO}_{4}$
$0.5 \mathrm{~g}, \mathrm{NaCl} 0.2 \mathrm{~g}, \mathrm{MgSO}_{4} .7 \mathrm{H}_{2} \mathrm{O} 0.1 \mathrm{~g}, \mathrm{KCl} 0.2 \mathrm{~g}$, yeast extract $0.5 \mathrm{~g}, \mathrm{MnSO}_{4}$ trace, $\mathrm{FeSO}_{4} .7 \mathrm{H}_{2} \mathrm{O}$ trace, $\mathrm{pH}$ adjusted to 7.2 and dissolved in $1000 \mathrm{~mL}$ distilled water]. Bradyrhizobium inoculum was prepared in yeast mannitol broth (Somasegaran and Hoben, 1985) containing $\mathrm{K}_{2} \mathrm{HPO}_{4} 0.5 \mathrm{~g}$, mannitol $10.0 \mathrm{~g}$, $\mathrm{MgSO}_{4} .7 \mathrm{H}_{2} \mathrm{O} 0.2 \mathrm{~g}, \mathrm{NaCl} 1.0 \mathrm{~g}$, yeast extract $0.1 \mathrm{~g}, \mathrm{pH}$ adjusted to 7.0 and dissolved in $1000 \mathrm{~mL}$ distilled water.

After the emergence of seedlings, broth of Bradyrhizobium japonicum strain TAL 377 and Pseudomonas strain 54RB were applied with the help of a micropipette at the base of each seedling using $1 \mathrm{~mL}$ containing $10^{8}$ cells $/ \mathrm{mL}$ as measured by optical density using a Spectronic 21 at wavelength $520 \mathrm{~nm}$.

Leaf samples were collected 70 days after sowing for sugar and protein analysis. Sugar and protein estimation in leaves was done following the method of Johnson et al. (1966) and Lowry et al. (1951), respectively. At maturity seeds were dried, ground, weighed and acid-digested for determination of $\mathrm{N}$ and P contents following the methods of Cottenie (1980) and Winkleman et al. (1984). Composite soil samples were taken from each treatment and extraction was done using ammonium bicarbonate diethylene triamine pentaacetic acid (AB-DTPA) for determination of soil $\mathrm{NO}_{3}-\mathrm{N}$ and available $\mathrm{P}$ content.

Seed protein was calculated according to the formula:

$$
\% \text { protein }=\% \mathrm{~N} \times 5.61(\text { factor })(\text { Mosse, } 1990) .
$$

\subsection{Field experiment}

The experimental plot located at Quaid-I-Azam University, Islamabad (longitude $70^{\circ} 10^{\prime} \mathrm{E}$ and latitude $33^{\circ} 40^{\prime} \mathrm{N}$ ) was divided into twenty-four sub-plots, consisting of three rows, each measuring $3 \mathrm{~m}$ with row-to-row distance of $30 \mathrm{~cm}$ in each plot. Three replicates and eight treatments, as described above for the pot experiments, were arranged in a completely randomized block design. Weeds were removed manually as and when required. The soil was clay loam with $\mathrm{pH} 7.8, \mathrm{ECe}$ $0.42 \mathrm{dsm}^{-1} ; \mathrm{P}$ and $\mathrm{NO}_{3}-\mathrm{N}$ were $8 \mathrm{ppm}$ and $11 \mathrm{ppm}$, respectively. The same field was used for two consecutive years of experiments (2004 \& 2005).

Growing conditions were the same as described above for the pot experiments. Nitrogen at $30 \mathrm{~kg} / \mathrm{ha}$ (recommended dose) in the form of urea was applied in each plot, whereas $\mathrm{P}_{2} \mathrm{O}_{5}$ at $50 \mathrm{~kg} / \mathrm{ha}$ (recommended dose) in the form of single super phosphate (SSP) was applied per treatment plot at the time of sowing. Inoculation was done using sterilized carrier material (NARC carrier, Khalil et al., 1991). The carrier material was inoculated with the broth cultures of Bradyrhizobium and Pseudomonas (single and mixed). For this purpose, seeds were soaked in sugar solution and coated with the carrier material containing inocula at approx. $10^{8}$ cells $\mathrm{mL}^{-1}$.

Leaf sugar and protein analyses were carried out (70 days after sowing) following the methods of Dubo et al. (1956) as modified by Johnson et al. (1966) and Lowry et al. (1951), respectively. Number of nodules per plant was counted at flowering. For this purpose, five plants per plot were uprooted gently and washed with tap water carefully before counting nodules. At maturity (106 days after sowing), harvesting was done and 
shoot weight and root weight were determined on a per plant basis (five plants per plot). For grain yield, plants were harvested ( $1 \mathrm{~m}^{2}$ per plot) and threshed manually, and seeds were weighed in $\mathrm{g} / \mathrm{m}^{2}$ and the value was converted into $\mathrm{kg} / \mathrm{ha}$. The seed $\mathrm{N}$, seed $\mathrm{P}$, soil $\mathrm{N}$ and soil $\mathrm{P}$ were determined as described for the pot study.

\subsection{Solubilization index}

A loopful of culture of Pseudomonas (54RB) was used to inoculate Pikovskaya's agar (Pikovskaya, 1948) plates [containing insoluble tricalcium phosphate $2.5 \mathrm{~g} / \mathrm{L}$ ] and incubated at $28{ }^{\circ} \mathrm{C}$ for $7 \mathrm{~d}$. The Solubilization index was determined using the formula (Premono et al., 1996):

Solubilization Index $=\frac{\text { colony diameter }+ \text { halozone diameter }}{\text { colony diameter }}$.

\subsection{Indole acetic acid and gibberellic acid production}

For detection and quantification of indole acetic acid and gibberellic acid production by bacterial strains, broth culture (100 mL) of Bradyrhizobium and Pseudomonas was prepared in yeast mannitol agar and Pikovskaya's media, respectively. In the broth, L-tryptophan $(100 \mathrm{mg} / \mathrm{L})$ was added as a precursor for biosynthesis of indole acetic acid. After 7 days of growth at $28{ }^{\circ} \mathrm{C}$ on a rotary shaker, the bacterial cells were harvested by centrifugation at $10000 \mathrm{rpm}$ for $10 \mathrm{~min}$. The $\mathrm{pH}$ of the supernatant (i.e., cell-free growth medium) was adjusted to 2.8 with $\mathrm{HCl}$. Extraction of phytohormones was carried out by the method of Tien et al. (1979). An equal volume of ethyl acetate (Merck, Germany) was added to the cell-free liquid culture media adjusted to $\mathrm{pH}$ 2.5-3 and was mixed vigorously in a separating funnel. Ethyl acetate extraction was repeated three times and extracts were evaporated to dryness under a rotary film evaporator. The residues were dissolved in $1 \mathrm{~mL}$ methanol (Merck).

The samples were analyzed on HPLC (Shimadzu, C-R4A Chromatopac; SCL-6B System Controller) using a UV detector and C18 column $(39 \times 300 \mathrm{~mm})$. Pure indole acetic acid and gibberellic acid (Sigma, USA) were used as standards for identification and quantification of indole acetic acid and gibberellic acid produced by bacterial cells. Methanol: acetic acid:water (30:1:70; v/v) was used as a mobile phase at the rate of $1.5 \mathrm{~mL} / \mathrm{min}$ with a run time of $8 \mathrm{~min}$. For identification of hormones $100 \mu \mathrm{L}$ samples filtered through a 0.45 Millipore filter were injected into the column. The growth hormones were identified on the basis of the retention time of the standard indole acetic acid and gibberellic acid using a UV detector at $280 \mathrm{~nm}$ wavelength. The concentration of indole acetic acid and gibberellic acid was calculated on the basis of peak area.

\subsection{Experiment conducted in axenic conditions}

Soil collected from a farmer's field, air-dried and well mixed with sand (1:1), was autoclaved (three times) at $120{ }^{\circ} \mathrm{C}$ at $15 \mathrm{lb}$ pressure for $1 \mathrm{~h}$. The soil was checked for sterility before starting the experiments, by plating aliquots from serial dilutions of sterilized soil on agar plates and monitoring any growth. In sterilized plastic pouches ( $0.5 \mathrm{~kg}$ soil capacity) five seeds were sown and after germination thinned to 3 plants per pouch. The seedlings were grown for four weeks (July-August 2006) at a temperature of $25^{\circ} \mathrm{C}-30^{\circ} \mathrm{C}$, photoperiod of $12-13 \mathrm{~h}$ and relative humidity varying from $75-80 \%$. A starter dose of nitrogen of $0.01 \mathrm{~g}$ per pouch was applied in the form of urea, whereas $\mathrm{P}_{2} \mathrm{O}_{5}$ was applied at $0.135 \mathrm{~g}$ per treatment. Plants were watered daily to maintain moisture at field capacity. The colony-forming units were determined at weekly intervals for 4 weeks.

Broth culture of Bradyrhizobium and Pseudomonas containing $10^{8}$ cells $/ \mathrm{mL}$ was applied 10 days after sowing at the base of each seedling at $1 \mathrm{~mL}$ per plant. Plants were uprooted and soil was gently removed from the root surface and rhizosphere to make dilutions. Colony-forming units (CFU) of Bradyrhizobium and Pseudomonas per gram soil were determined by plating $100 \mu \mathrm{L}$ of tenfold serial dilution on respective culture media. The CFU was calculated according to James (1978).

$$
\text { Colony-forming unit }=\frac{\text { number of colonies } \times \text { dilution factor }}{\text { volume of inoculum }}
$$

\subsection{Statistical analysis}

The data obtained in the study were averaged for two years for pot as well as field experiments and then subjected to analysis of variance using MSTAT-C software (Bricker, 1991) and means were compared by Duncan's Multiple Range Test (Duncan, 1955). Correlations between growth parameters were also calculated (Bricker, 1991).

\section{RESULTS AND DISCUSSION}

\subsection{Phytohormone production and phosphate solubilization}

Bradyrhizobium japonicum strain TAL 377 produced $74.64 \mu \mathrm{g} / \mathrm{mL}$ indole acetic acid (IAA) and $261.2 \mu \mathrm{g} / \mathrm{mL}$ gibberellic acid, and Pseudomonas strain 54RB produced $8.034 \mu \mathrm{g} / \mathrm{mL}$ IAA and $1766 \mu \mathrm{g} / \mathrm{mL}$ gibberellic acid, and exhibited a phosphorus solubilization index of 4.1. It was observed that this strain, which produced the highest amount of auxins and gibberellins, also caused maximum increase in growth and yield.

\subsection{Pot experiment}

Shoot/root weight, plant height, number of pods, grain yield, and leaf sugar and leaf protein content showed maximum increase over control in the Bradyrhizobium Pseudomonas $\mathrm{P}_{2} \mathrm{O}_{5}$ treatment (Tab. I). Increase in root/shoot 
A. Afzal et al.

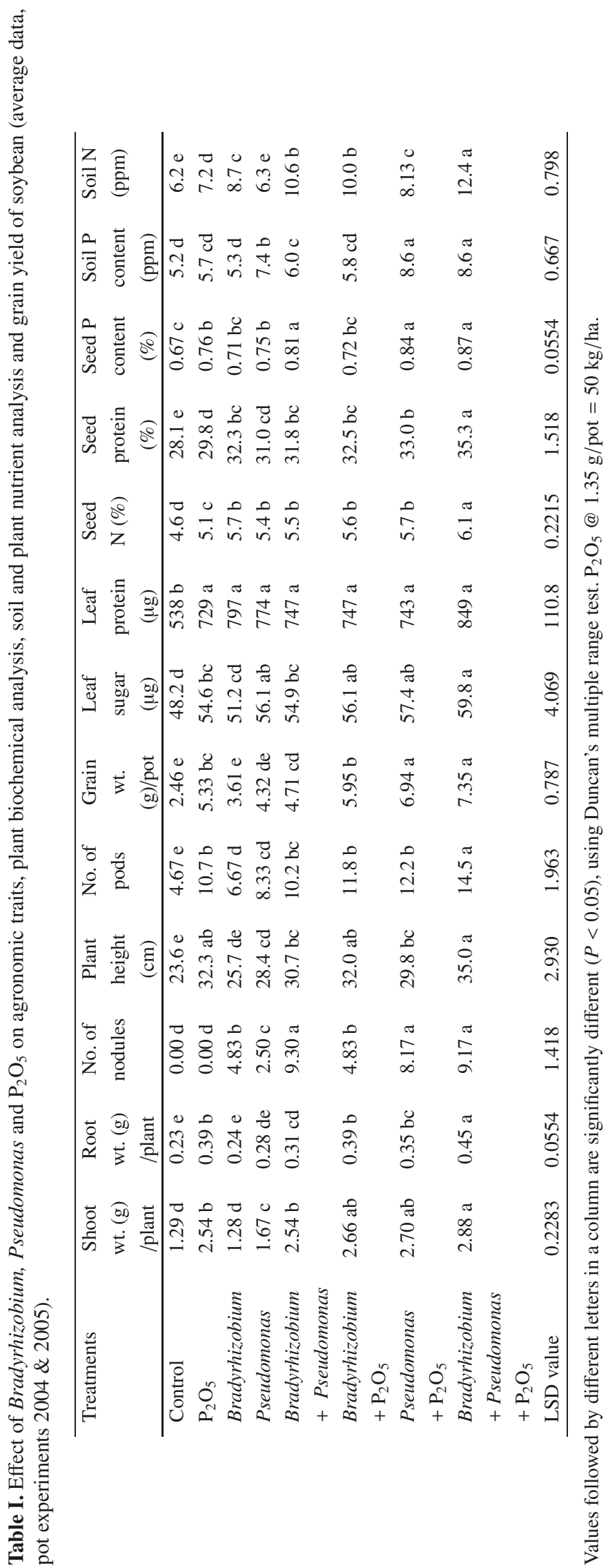




\section{Survival of Bradyrhizobium in the rhizosphere}

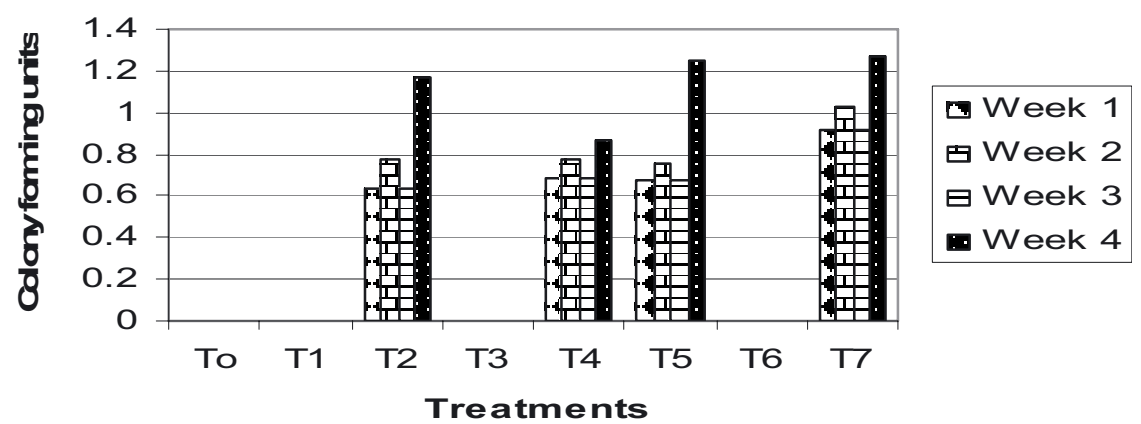

To. control T1. $\mathrm{P}_{2} \mathrm{O}_{5}$ T2. Bradyrhizobium T3. Pseudomonas T4. Bradyrhizobium + Pseudomonas T5. Bradyrhizobium $+\mathrm{P}_{2} \mathrm{O}_{5}$ T6. Pseudomonas $+\mathrm{P}_{2} \mathrm{O}_{5}$ T7. Bradyrhizobium + Pseudomonas $+\mathrm{P}_{2} \mathrm{O}_{5}$.

Figure 1. Colony-forming units of Bradyrhizobium per gram rhizosphere soil as affected by different treatments. These counts were taken after the 1st, 2nd, 3rd and 4th weeks of seedling growth of soybean. The values represent the average of three replicates multiplied by $10^{6}$.

\section{Survival of Pseudomonas in the rhizosphere}

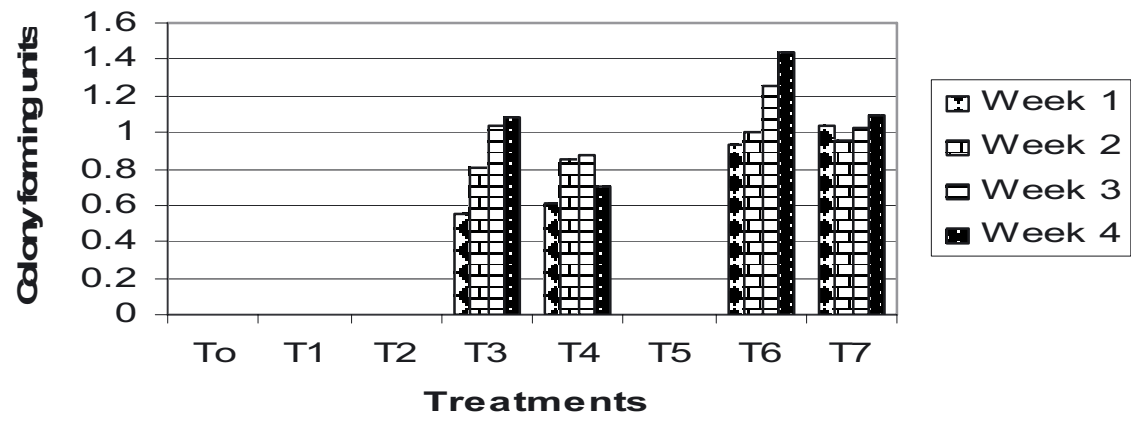

To. control T1. $\mathrm{P}_{2} \mathrm{O}_{5}$ T2. Bradyrhizobium T3. Pseudomonas T4. Bradyrhizobium + Pseudomonas T5. Bradyrhizobium $+\mathrm{P}_{2} \mathrm{O}_{5}$ T6. Pseudomonas $+\mathrm{P}_{2} \mathrm{O}_{5}$ T7. Bradyrhizobium + Pseudomonas $+\mathrm{P}_{2} \mathrm{O}_{5}$.

Figure 2. Colony-forming units of Pseudomonas per gram rhizosphere soil as affected by different treatments. These counts were taken after the $1 \mathrm{st}, 2 \mathrm{nd}, 3 \mathrm{rd}$ and 4 th weeks of seedling growth of soybean. The values represent the average of three replicates multiplied by $10^{6}$.

weight of soybean due to co-inoculation of Bradyrhizobium japonicum and phosphate-solubilizing bacteria could be attributed to phytohormone production by these microbes, resulting in root proliferation, as has been reported by Bai-Yu Ming et al. (2003), Gautam and Pant (2002) and Tomar et al. (2004).

Maximum numbers of nodules were produced with Bradyrhizobium and Pseudomonas. This result may be due to the greater survival efficiency of these microbes as observed by higher colony-forming unit values when Bradyrhizobium and Pseudomonas were co-inoculated (Figs. 1 and 2), indicating the synergistic effect of the two microbes on root nodulation. The minimum number of nodules was noted in plants where only Pseudomonas was applied. It explains the role of phosphorus solubilizers in the process of nodule formation and $\mathrm{N}$ fixation through phosphorus bioavailability in the root zone. The importance of $\mathrm{P}$ solubilizers is also obvious from the observation that no nodule was produced in $\mathrm{P}_{2} \mathrm{O}_{5}$ treatment alone. The possibility of contamination could not be ignored, but similar results in the field open a gateway to further research on nodule formation with species other than Bradyrhizobium on one hand, and the effectiveness of Bradyrhizobium in the presence of any P solubilizer, on the other hand. The coinoculation treatment of Bradyrhizobium and Pseudomonas in the presence of $\mathrm{P}_{2} \mathrm{O}_{5}$ increased number of pods $(36 \%$ over $\mathrm{P}_{2} \mathrm{O}_{5}$ ), grain yield (38\% higher than $\mathrm{P}_{2} \mathrm{O}_{5}$ ), seed $\mathrm{N}$ and $\mathrm{P}$, and available $\mathrm{P}$ and $\mathrm{N}$ content (51 and $72 \%$ over $\mathrm{P}_{2} \mathrm{O}_{5}$, respectively) of soil, indicating the positive role of these microbes in nutrient mobilization and ultimately increasing yield of soybean.

In most studies interpretation of the effects of phosphorus on host plant growth, nodule formation and $\mathrm{N}$ fixation has been made. In the present study, the host plant was also inoculated with phosphorus-solubilizing bacteria along with phosphorus 
A. Afzal et al.

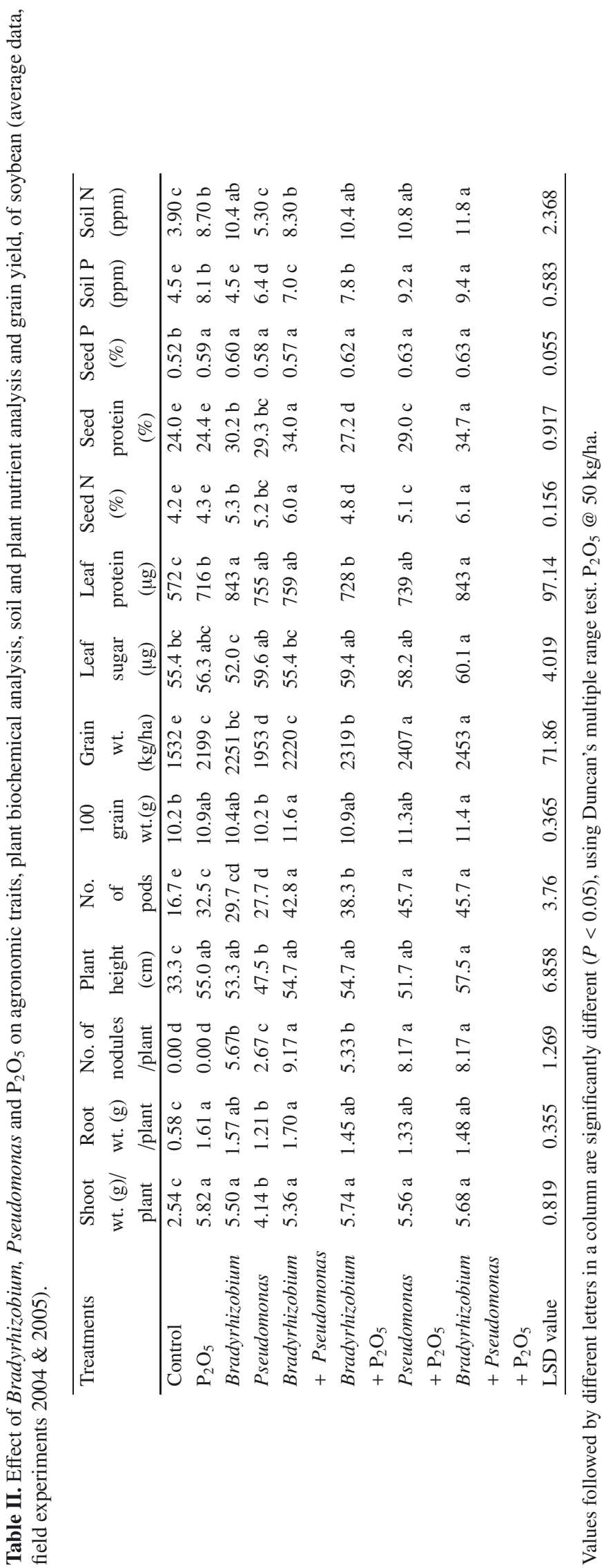


fertilizer (recommended dose only) for enhanced supply of phosphorus for nodule formation, $\mathrm{N}$ fixation and ultimately, growth of the host legume plant, and the results indicated that this treatment has a profound effect on nodule number, nutrient uptake, growth and final grain yield of soybean. This bacterial strain has not been tested before for its potential as a co-inoculant with Bradyrhizobium in soybean at the pot and field level.

In pot experiments broth culture inoculum application in the rhizosphere is feasible and is generally practiced by the scientific community for testing the potential of new bacterial strains to be used as biofertilizer. A comparison of the pot and field studies with respect to broth inoculation and seed coating methods indicated that in general both these methods are effective and produce similar results in the pot and field, although some exceptions were also observed.

\subsection{Field experiment}

Maximum shoot weight was observed with the $\mathrm{P}_{2} \mathrm{O}_{5}$ treatment (129\% over control), followed by the Bradyrhizobium and $\mathrm{P}_{2} \mathrm{O}_{5}$ treatment (126\% over control) (Tab. II). This result showed that inoculation did not play its role in improving plant shoot weight in the field. The difference in response to inoculation between the field and pot may be attributed to the difference in root exudation from host plants, production of microbial metabolites and soil nutrients exposed to the larger area of the field, which are under the influence of climatic conditions accompanied by losses due to leaching. Maximum root weight and the highest number of nodules was recorded in the Bradyrhizobium and $\mathrm{P}_{2} \mathrm{O}_{5}$ treatment. It was interesting to note that plants inoculated with Pseudomonas alone also produced nodules. The possibility of contamination cannot be overruled. However, increased nodulation due to phosphate solubilizer (Sordaria fimicola) and phosphorus sources has previously been reported by Rasal et al. (2004) and Paratey and Wani (2005). Increasing available phosphorus frequently increases $\mathrm{N}_{2}$ fixation in Rhizobium (Andrade et al., 1998). Tilak et al. (2006) reported that the PGPR isolates used did not antagonize the introduced Rhizobium strain and dual inoculation with either Pseudomonas putida, P. fluorescens or Bacillus cereus resulted in a significant increase in plant growth, nodulation and enzyme activity over Rhizobium-inoculated and uninoculated control plants. The nodule occupancy of the introduced Rhizobium strain increased from 50\% (with Rhizobium alone) to $85 \%$ in the presence of Pseudomonas putida. Increase in number of nodules in Bradyrhizobium and Pseudomonas coinoculation may be due to Pseudomonas-induced phosphorus solubilization as well as increased production of gibberellic acid, which increases root proliferation and stimulates plant growth. Number of nodules was correlated with leaf protein $\left(\mathrm{r}=0.64^{* *}\right)$, seed $\mathrm{N}$ content $\left(\mathrm{r}=0.85^{* *}\right)$ and soil $\mathrm{N}$ content $(\mathrm{r}=0.67 * *)$.

Similarly to the pot experiments, co-inoculation of Bradyrhizobium + Pseudomonas in the presence of $\mathrm{P}_{2} \mathrm{O}_{5}$ resulted in maximum increase in plant height, number of pods, grain yield, leaf sugar and protein content. Increased plant height by co-inoculation of Bradyrhizobium and Pseudomonas along with $\mathrm{P}_{2} \mathrm{O}_{5}$ may possibly be attributed to the inoculationinduced increase in indole acetic acid and gibberellic acid production, which subsequently increased the cell division and cell elongation. The grain yield with co-inoculation of Bradyrhizobium and Pseudomonas in the presence of $\mathrm{P}_{2} \mathrm{O}_{5}$ was $37.89 \%$ in pot experiments and $11.55 \%$ in the field compared with $\mathrm{P}_{2} \mathrm{O}_{5}$ alone. In a comparison of the last two treatments (Tabs I and II) it was noted that in the field study the grain yield was $09 \%$ higher than $\mathrm{P}_{2} \mathrm{O}_{5}$ when Pseudomonas was used along with $\mathrm{P}_{2} \mathrm{O}_{5}$ and $12 \%$ higher than $\mathrm{P}_{2} \mathrm{O}_{5}$ when Bradyrhizobium and Pseudomonas were used along with $\mathrm{P}_{2} \mathrm{O}_{5}$ as compared with the pot study, where this increase was 38 and 30\%, respectively. Increased plant growth of soybean inoculated with Bradyrhizobium and Pseudomonas has been reported by Zaidi and Singh (2001). However, in our study supplemented $\mathrm{P}_{2} \mathrm{O}_{5}$ further enhanced the yield. The size of grain as indicated by 100 -grain weight was significantly higher in the co-inoculation treatment even in the absence of $\mathrm{P}_{2} \mathrm{O}_{5}$. Usman et al. (2004) have reported increased number of pods, grain weight and yield with a mixture of rhizobial strains including TAL 377 in soybean. Increase in grain yield due to co-inoculation of Bradyrhizobium and phosphate-solubilizing bacteria has been reported by Zaidi et al. (2004) in green gram, and Tapas and Gupta (2005) and Jain and Trivedi (2005) in soybean. In our study it was observed that co-inoculation of synergistic microbes is benefited by phosphatic fertilizer application. It is evident from the colony-forming unit (CFU) values of the applied microbes in the rhizosphere as well. Number of pods was highly correlated with grain yield, seed $\mathrm{N}$ and seed $\mathrm{P}$. These results may be due to the production of growth-promoting substances and high colonization ability of rhizobacteria such as Pseudomonas because they enhance the nitrogen fixation of soybean when co-inoculated with Bradyrhizobium japonicum (Chebotar et al., 2001).

Maximum seed $\mathrm{P}, \mathrm{N}$ and protein were recorded by Bradyrhizobium-Pseudomonas $-\mathrm{P}_{2} \mathrm{O}_{5}$ treatment. Similarly, maximum soil $\mathrm{P}$ as well as soil $\mathrm{NO}_{3}-\mathrm{N}$ was recorded with Bradyrhizobium-Pseudomonas $-\mathrm{P}_{2} \mathrm{O}_{5}$. Pseudomonas alone also improved soil P. Zaidi et al. (2004), Govindan and Thirumurugan (2005), and Zaidi and Singh (2001) reported significant increases in seed $\mathrm{P}$ of different legumes due to co-inoculation of Rhizobium and PSB over control. Jain and Trivedi (2005) and Lanje et al. (2005) have reported increases in seed protein of soybean due to Bradyrhizobium japonicum and $\mathrm{P}$ solubilizers alone or in combination. Govindan and Thirumurugan (2005) reported significantly increased postharvest soil $\mathrm{N}$ and $\mathrm{P}$ levels in soybean due to co-inoculation of Bradyrhizobium and Pseudomonas. Addition of P fertilizer was again comparable with these studies.

The results indicate that although BradyrhizobiumPseudomonas $-\mathrm{P}_{2} \mathrm{O}_{5}$ was the best treatment for most of the growth and yield parameters, this is followed by Pseudomonas $-\mathrm{P}_{2} \mathrm{O}_{5}$ in the case of yield, sugar content and seed as well as soil $\mathrm{P}$ content. Bradyrhizobium $-\mathrm{P}_{2} \mathrm{O}_{5}$ was also effective for improving root/shoot weight, plant height, number of pods and grain yield of soybean. Bradyrhizobium has a favorable 
effect on number of nodules, and soil and seed $\mathrm{N}$ content, as well as leaf and seed protein content.

\subsection{Experiment conducted under axenic conditions}

The colony-forming unit (CFU) of Bradyrhizobium was non-significantly affected in the presence of Pseudomonas or $\mathrm{P}_{2} \mathrm{O}_{5}$ applied separately, but in the presence of both Pseudomonas and $\mathrm{P}_{2} \mathrm{O}_{5}$ the colony-forming unit of Bradyrhizobium was significantly higher at all measurements for 4 weeks. In measurements made 4 weeks after inoculation, Bradyrhizobium showed a decrease in colony-forming unit when coinoculated with Pseudomonas, but a significant increase in colony-forming unit was recorded in the presence of $\mathrm{P}_{2} \mathrm{O}_{5}$ or Pseudomonas $-\mathrm{P}_{2} \mathrm{O}_{5}$. There was no significant effect of Bradyrhizobium inoculation on Pseudomonas until the 2nd week of measurement; thereafter, co-inoculation of Bradyrhizobium and Pseudomonas resulted in a significant decrease in colony-forming unit count. However, co-inoculation with Bradyrhizobium in the presence of $\mathrm{P}_{2} \mathrm{O}_{5}$ significantly stimulated colony-forming unit counts of Pseudomonas at all measurements for 4 weeks. The magnitude of the increase was significantly higher for Pseudomonas in the presence of $\mathrm{P}_{2} \mathrm{O}_{5}$ only. Phosphorus plays a key role in improving the density of Rhizobium in the rhizosphere (Anonymous, 1999). Tapas and Gupta (2005) reported that dual inoculation of bacterial cultures enhances the rhizobial and phosphate-solubilizing bacteria population in the rhizosphere. It is inferred that survival of Bradyrhizobium and Pseudomonas was higher when they were co-inoculated in the presence of $\mathrm{P}_{2} \mathrm{O}_{5}$ as compared with when they were single-inoculated. This may be due to availability of phosphorus in the form of $\mathrm{P}_{2} \mathrm{O}_{5}$. The benefit of $\mathrm{P}_{2} \mathrm{O}_{5}$ to Pseudomonas was evident from the 1st week, while Bradyrhizobium benefited from $\mathrm{P}_{2} \mathrm{O}_{5}$ at a later stage. The survival efficiency of Bradyrhizobium was up to $46 \%$ higher due to coinoculation and $\mathrm{P}_{2} \mathrm{O}_{5}$ as compared with its single inoculation while, on the other hand, Pseudomonas' survival efficiency was up to $33 \%$ higher with added $\mathrm{P}_{2} \mathrm{O}_{5}$ as compared with its single inoculation. So it is inferred that Bradyrhizobium requires $P$ sources along with P solubilizer for increased survival in the rhizosphere.

\section{CONCLUSION}

It is inferred from this investigation that co-inoculation of these $\mathrm{N}$-fixing and $\mathrm{P}$-solubilizing microorganisms in the presence of $\mathrm{P}_{2} \mathrm{O}_{5}$ is very effective in increasing grain yield of soybean on a sustainable basis by up to $12-38 \%$ as compared with only $\mathrm{P}_{2} \mathrm{O}_{5}$ fertilizer. This study strengthens the efforts of combating the phosphorus fixation issue for wise use of this non-renewable natural resource for leguminous crops. Available soil P content was improved following inoculation with Psolubilizing bacteria and Pseudomonas also assisted Bradyrhizobium in increasing soil $\mathrm{N}$ level. The response to inoculated microorganisms showed a similar trend in pot and field experiments, with some exceptions. The co-inoculation of two microbes has been reported to have both synergistic and antagonistic responses; however, during the present investigation the co-inoculation of Bradyrhizobium and Pseudomonas increased the number of these microbes in the presence of $\mathrm{P}_{2} \mathrm{O}_{5}$, suggesting that $\mathrm{P}_{2} \mathrm{O}_{5}$ may assist Bradyrhizobium colonization and growth. Production of plant growth regulators, P solubilization activity and increased colonization in the rhizosphere suggest the mechanism of action of co-inoculated $\mathrm{N}$-fixing and P-solubilizing microorganisms. It is suggested that in developing countries such as Pakistan, beneficial microbial consortia should be formulated for important crops and disseminated to farmers by extension workers for improvement in yield on a sustainable basis with less use of costly non-renewable depleted natural resources.

\section{REFERENCES}

Andrade G., De Leij F.A.A.M., Lynch J.M. (1998) Plant mediated interactions between Pseudomonas fluorescens, Rhizobium leguminosarum and arbuscular mycorrhizae on pea, Lett. Appl. Microbiol. $26,311-316$.

Anonymous (1999) Effect of phosphorus on nitrogen fixation, Better Crops, International Plant Nutrition Institute, USA, Vol. 83, pp. 3031.

Bai-Yu Ming, Zhou-Xiao Min, Smith D.L. (2003) Enhanced soybean plant growth resulting from coinoculation of Bacillus strains with Bradyrhizobium japonicum, Crop Sci. 43, 1774-1781.

Bricker B. (1991) MSTATC. A micro computer programme for the design, manage and analysis of agronomic research expt. Crop and Sci. Dept., AUS, Lansin USA.

Chebotar V.K., Asis C.A., Akao S. (2001) Production of growthpromoting substances and high colonization ability of rhizobacteria enhance the nitrogen fixation of soybean when coinoculated with Bradyrhizobium japonicum, Biol. Fert. Soils 34, 427-432.

Cottenie A. (1980) Soil and Plant testing as a basis of fertilizer recommendations, FAO, Soil's Bull. 38, 64-65.

Dubo S.M., Giles K.A., Hamilton J.K., Rebers P.A., Smith F.A. (1956) Calorimetric method for determination of sugar and related substances, Anal. Chem. 28, 350.

Duncan D.B. (1955) Multiple range and multiple F- test, Biometrics 11, $1-42$.

Gautam P., Agnihotri A.K., Pant L.M. (2003) Effect of phosphorus rate and Pseudomonas species in combination with Bradyrhizobium japonicum and farmyard manure on seed yield and yield attributes of soybean (Glycine max L.), Indian J. Agr. Sci. 73, 426-428.

Gautam P, Pant L.M. (2002) Effect of coinoculation of Pseudomonas species and Bradyrhizobium japonicum on nitrogen and phosphorus availability to soybean (Glycine max L.), Indian J. Agr. Sci. 72, $248-251$

Govindan K., Thirumurugan V. (2005) Synergistic association of Rhizobium with phosphate-solubilizing bacteria under different sources of nutrient supply on productivity and soil fertility in soybean (Glycine max L), Indian J. Agron. 50, 214-217.

Israel D.W. (1987) Investigation of the role of phosphorus in symbiotic dinitrogen fixation, Plant Physiol. 84, 835-840.

Israel, D.W. (2006) Symbiotic dinitrogen fixation and host-plant growth during development of and recovery from phosphorus deficiency, Physiol. Plantarum 88, 294-300.

Jain P.C., Trivedi S.K. (2005) Response of soybean (Glycine max (L.) Merrill) to phosphorus and biofertilizers, Legume Res. 28, 30-33. 
James G.C. (1978) Natallic Sherman Rockland Community College, State University of New York, The Benjamin/Coming publishing Company, Inc., pp. 75-80.

Johnson R.R., Balwani T.L., Johnson L.J., Meclure K.E., Denority B.A. (1966) Corn plant matyrity. II. Effect on in-vitro cellular digestibility and soluble carbohydrate content, J. Anim. Sci. 25, 617.

Khalil S., Khokhar S.N., Khan M.A. (1991) Evaluation of an indigenous soil as Rhizobium carrier, Pak. J. Agric. Res. 12, 62-65.

Kucey, R.M.N., Janzen H.H., Leggett M.E. (1989) Microbially mediated increases in plant-available phosphorus, Adv. Agron. 42, 199-228.

Lanje P.W., Buldeo A.N., Zade S.R., Gulhane V.G. (2005) The effect of Rhizobium and phosphorous solubilizers on nodulation, dry matter, seed protein, oil and yield of soybean, J. Soils Crops 15, 132-135.

Lowry O.H., Rosbrough N.J., Farr A.L., Randall R.J. (1951) Protein measurement with the folin phenol reagent, J. Biol. Chem. 193, 265-75.

Miao S.J., Qiao Y.F., Han X.Z., An M. (2007) Nodule formation and development in soybeans (Glycine $\max$ L.) in response to phosphorus supply in solution culture, Pedosphere 17, 36-43.

Mosse J. (1990) $\mathrm{N}$ to protein conversion factor for ten cereals and six legumes, J. Agr. Food Chem. 38, 18-24.

Paratey P.R., Wani P.V. (2005) Response of soybean (cv. JS-335) to phosphate solubilizing biofertilizers, Legume Res. 28, 268-271.

Pikovskaya R.I. (1948) Mobilization of phosphorus in soil in connection with the vital activity of some microbial species, Mikrobiologiya 17, 362-370.

Premono E., Moawad M.A., Vleck P.L.G. (1996) Effect of phosphate solubilizing Pseudomonas putida on the growth of maize and its survival in the rhizosphere, Indonasian J. Crop Sci. 11, 13-23.

Rasal P.H., Sangale B.B., Pawar K.B. (2004) Effects of phosphate solubilizing and sulphur oxidizing microorganisms on yield and phosphorus uptake of soybean, J. Maharashtra Agric. Universities 29, 51-53.

Robert J.W. (1986) The soybean solution: Meeting world food needs. NIT-College of Agriculture, University of Illinois at Urbana, Champaign, USA, 1 Bulletin, pp. 4-27.

Somasegaran P., Hoben H.J. (1985) Methods in legume-Rhizobium technology, NifTAL project and MIRCEN, Dep. Agron. and Soil Sci., Hawaii Inst. Trop. Agri. Human Res. Univ. Hawaii Manoa.
Tapas C., Gupta S.B. (2005) Effect of bacterial fertilizers with different phosphorus levels on soybean and soil micro flora, Adv. Plant Sci. $18,81-86$.

Tien T.M., Gaskind M.H., Hubbel D.H. (1979) Plant growth substances produced by Azospirillum brasilense and their effect on growth of pearl millet (Pennisetum americanum L.), Appl. Environ. Microb. 37, 1016-1024.

Tilak K.V.B.R., Ranganayaki N., Manoharachari C. (2006) Synergistic effects of plant-growth promoting rhizobacteria and Rhizobium on nodulation and nitrogen fixation by pigeonpea (Cajanus cajan), Eur. J. Soil Sci. 57, 67-71.

Tomar S.S., Singh R., Singh S.P. (2004) Response of phosphorus, sulphur and Rhizobium inoculation on growth, yield and quality of soybean (Glycine $\max$ L.), Progressive Agric. 4, 72-73.

Tsvetkova G.E., Georgiev G.I. (2003) Effect of phosphorus nutrition on the nodulation, nitrogen fixation and nutrient use efficiency of Bradyrhizobium japonicum-soybean (Glycine max L. Merr.) symbiosis, Bulg. J. Plant Physiol. Special Issue, 331-335.

Usman M., Parveen L., Ahmad B. (2004) Effect of different strains of Rhizobium japonicum on the yield and yield components of soybean planted under Malakand (NWFP) conditions, Ind. J. Plant Sci. 3, 459-464.

Vance C.P. (2001) Symbiotic nitrogen fixation and phosphorus acquisition. Plant nutrition in a world of declining renewable resources, Plant Physiol. 127, 390-397.

Winkleman G.E., Macleod J.G., McAndrew D.W. (1984) Chemical methods of soil, plant, water and blood analysis, Agriculture Canada, Swift Current, Saskatchewan, Canada.

Zaidi A., Khan M.S., Aamil M. (2004) Bioassociative effect of rhizospheric microorganisms on growth, yield, and nutrient uptake of greengram, J. Plant Nutr. 27, 601-612.

Zaidi S.F.A., Singh H.P. (2001) Effect of dual inoculation of fluorescent Pseudomonas and Bradyrhizobium japonicum on nutrient uptake plant growth, nodulation and yield of soybean (Glycine max (L) Merr.), Appl. Biol. Res. 3, 1-8. 